$$
\text { CONF-970424--16 }
$$

\title{
Determination of Long-Lived Fission Products and Actinides in Savannah River Site HLW Sludge and Glass for Waste Aceptance
}

by

N. E. Bibler

Westinghouse Savannah River Company

Savannah River Site

Aiken, South Carolina 29808

W. T. Boyce

C. J. Coleman

W. F. Kinard

Dept of Chemistry, College of Charleston

SC USA

A document prepared for FOURTH INTERNATIONAL CONFERENCE ON METHODS OF RADIOANALYTICAL

CHEMISTRY at Kona, HW, USA from 4/6/97 - 4/11/97.

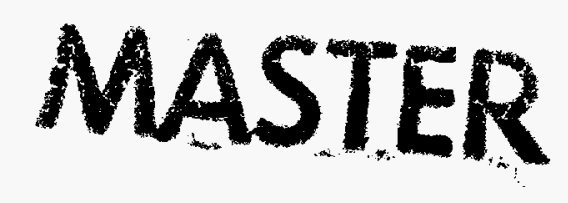

DISTREUTION OF THS DOWUENT IS UNLMED

DOE Contract No. DE-AC09-89SR18035

This paper was prepared in connection with work done under the above contract number with the U.S. Department of Energy. By acceptance of this paper, the publisher and/or recipient acknowledges the U.S. Government's right to retain a nonexclusive, royalty-free license in and to any copyright covering this paper, along with the right to reproduce and to authorize others to reproduce all or part of the copyrighted paper. 


\section{DISCLAIMER}

This report was prepared as an account of work sponsored by an agency of the United States Government. Neither the United States Government nor any agency thereof, nor any of their employees, makes any warranty, express or implied, or assumes any legal liability or responsibility for the accuracy, completeness, or usefulness of any information, apparatus, product, or process disclosed, or represents that its use would not infringe privately owned rights. Reference herein to any specific commercial product, process, or service by trade name, trademark, manufacturer, or otherwise does not necessarily constitute or imply its endorsement, recommendation, or favoring by the United States Government or any agency thereof. The views and opinions of authors expressed herein do not necessarily state or reflect those of the United States Government or any agency thereof.

This report has been reproduced directly from the best available copy.

Available to DOE and DOE contractors from the Office of Scientific and Technical Information, P. O. Box 62, Oak Ridge, TN 37831; prices available from (423) 576-8401.

Available to the public from the National Technical Information Service. U. S. Department of Commerce, 5285 Port Royal Rd., Springfield, VA 22161 


\section{DISCLAMIER}

Portions of this document may be illegible in electronic image products. Images are produced from the best available original document. 
WSRC-MS-97-0011

Keywords: Waste Acceptance, DWPF Glass, radioactive waste

DETERMINATION OF LONG-LIVED FISSION PRODUCTS AND ACTINIDES IN SAVANNAH RIVER SITE HLW SLUDGE AND GLASS FOR WASI'E ACCEPTANCE

by N. E. Bibler, W. F. Kinard*, W. T. Boyce, and C. J. Coleman

Westinghouse Savannah River Company

Savannah River Technology Center

Westinghouse Savannah River Co.

Aiken, SC 29808

* Departmant of Chemsitry

College of Charleston

Charleston, SC 29424

A paper for presentation at the Fourth International Conference on Methods and Applications of Radioanalytical Chemistry, April 6 to April 11, 1997, in Kona, Hawaii, USA, and for Publication in Journal of Radionanalytical Chemistry

This paper was prepared in connection with work done under contract No. DE-AC09-89SR18035 with the U.S. Department of Energy. By acceptance of this paper, the publisher and/or recipient acknowledges the U.S. Government's right to retain a nonexclusive, royalty-free license in and to any copyright covering this paper, along with the right to reproduce and to authorize others to reproduce all or part of the copyrighted paper. 
DETERMINATION OF LONG-LIVED FISSION PRODUCTS AND ACTINIDES IN SAVANINAH RIVER SITE HLW SLUDGE AND GLASS FOR WASTE ACCEPTANCE

N. E. Bibler, W. F. Kinard*, W. T. Boyce, and C. J. Coleman

Savannah kiver Technology Center

Westinghouse Savannah River Co.

Aiken, SC USA 29808

*Department of Chemistry

College of Charleston

Charles, SC 29424

\section{ABSTRACT}

Savannah River Site (SRS) is currently immobilizing the radioactive, caustic, high-level waste sludge in Tank 51 into a borosilicate glass for disposal in a geologic repository. A requirement for repository acceptance is that SRS report the concentrations of certain fission product and actinide radionuclides in the glass. This paper presents measurements of many of these concentrations in both Tank 51 sludge and the final glass. The radionuclides were measured by inductively coupled plasma - mass spectrometry and $\alpha, \beta$, and $\gamma$ counting methods. Examples of the radionfuclides are Sr-90, $\mathrm{Cs}-137, \mathrm{U}-238, \mathrm{Pu}-239$, and $\mathrm{Cm}-244$. Concentrations in the glass are 3.1 times lower due to dilution of the sludge with a nonradioactive glass forming frit in the vitrification process. Results also indicated that in both the sludge and glass the relative concentrations of the long lived fission products insoluble in caustic are in proportion to their yields from the fission of U-235 in the SRS reactors. This allowed the calculation of a fission yield scaling factor. 
This factor in addition to the sludge dilution factor can be used to estimate concentrations of waste acceptance radionuclides that cannot be measured in the glass. Examples of these radionuclides are Se-79, $\mathrm{Zr}-93$, and $\mathrm{Pd}-107$.

\section{INTRODUCTION}

Savannah River Site (SRS) is currently immobilizing its radioactive high-level waste ( $\mathrm{HLW}$ ) sludge into a borosilicate glass in the Defense Waste Processing Facility (DWPF). This glass will eventually be placed in a geologic repository for permanent disposal. The HLW resulted from operations at SRS to produce Pu-239 and other special isotopes for the U. S. It is stored as caustic sludge slurries or supernates in underground steel tanks. In the waste management practices at SRS, the sludge slurries and supernates are separated and stored in separate tanks. As a result the sludge slurries contain those radionuclides that are primarily insoluble in caustic, and the supernates contain those that are soluble. The main radionuclides in the sludge slurries are $\mathrm{Sr}-90$ and actinides. In the supernates, the primary radionuclide is Cs-137 which has an appreciable solubility in caustic.

Eventually all the HLW at SRS will be immobilized into a borosilicate glass. Currently the DWPF is immobilizing the sludge slurry from SRS Tank 51. One of the requirements for repository acceptance and final disposal of the glass is that SRS report how many Curies of certain fisision products and actinides are in the glass. This specification states that the glass producer shall report the amount or concentration of each radionuclide in the glass that has a half life longer than 10 years and will be present in concentrations greater than 0.05 percent of the total radioactivity in Curies out to approximately 3000 years. ${ }^{1}$. The purpose of this specification is to provide a radionuclide source term necessary to assess 
the long term performance of the repository. Examples of radionuclides that need to be reported are shown in Table 1 .

All of the radionuclides in Table 1 can be measured in Tank 51 sludge and glass except Se-79, Zr-93, and Pd-107. This paper reports results of these measurements. The principle analytical technique was inductively coupled plasma - mass spectrometry. Results for many other fission products and actinides are also presented. For the fission products, the results indicate that for the long lived and stable products that are insoluble in caustic, their respective concentrations are in proportion to their yields from fission of U-235 in the SRS reactors. Lastly, based on this information and on the composition of the sludge and glass, a method is presented for determining the concentrations of the waste acceptance radionuclides that could not be measured in the glass (Se-79, Zr-93, and Pd-107).

\section{EXPERIMENTAL}

\section{Glass Preparation}

In the Shielded Cells of Savannah River Technology Center, $10 \mathrm{~kg}$ of Tank 51 radioactive sludge (on a dry basis) were used to demonstrate the DWPF process for vitrification of HLW sludge. Details of this campaign have been published. 2 The sludge was washed to lower its $\mathrm{Na}$ content and the washed slurry mixed with $19 \mathrm{~kg}$ of nonradioactive SRS Frit 202 in order to make glass. The final slurry ( 40 wt: solids) was fed to a joule heated, remotely operated melter in the Shielded Cells. The temperature of the melter was $1150^{\circ} \mathrm{C}$. Approximately $31 \mathrm{~kg}$ of glass were produced. The sludge for the demonstration was fully characterized, which included measuring the concentrations of sixty-four radioactive and nonradioactive isotopes. The glass produced in the 
demonstration was also fully characterized, including measuring the sixty-four isotopes.

\section{Sludge and Glass Dissolution Methods}

Samples of both sludge and glass from the demonstration were dissolved by two different methods. This ensured that all the elements (excluaing $\mathrm{O}_{2}$ ) could be determined. Dissolutions were performed remotely in the Shielded Cells. Prior to dissolution, the sludge slurry was dried at $100^{\circ} \mathrm{C}$. Pieces of the glass were crushed, ground, and then sieved through a 200 mesh sieve. The -200 mesh fraction was used for the dissolutions. In both dissolution methods, 0.25 grams of sample were dissolved. Both the sludge and glass were dissolved by a $\mathrm{Na}_{2} \mathrm{O}_{2}$ fusion technique. Experience showed that this method was best for $\mathrm{Si}$ and noble metal fission products. For this method, 0.25 grams of sample were mixed with 1.5 grams of $\mathrm{Na}_{2} \mathrm{O}_{2}$ and 1 gram of $\mathrm{NaOH}$ in a $\mathrm{Zr}$ or $\mathrm{Ni}$ crucible. The mixture was then heated at $600^{\circ} \mathrm{C}$ for 15 minutes. The fused material was allowed to cool and then quantitatively transferred with deionized water to $a=250 \mathrm{~mL}$ volumetric flask. After the transfer, $25 \mathrm{~mL}$ of conc. $\mathrm{HNO}_{3}$ or HCl was added to the flask and then the solution was diluted to $250 \mathrm{~mL}$ with deionized water. It was found that $20 \mathrm{~mL}$ of this solution could be removed from the cell without causing excess radiation exposure to personnel performing the analyses. The samples of sludge were dissolved using aqua regia ( $9 \mathrm{~mL}$ of conc. HCL and $3 \mathrm{~mL}$ of concl. HNO3) that was prepared in the cell just prior to use. The dissolution took place in a sealed Teflon vessel at $95^{\circ} \mathrm{C}$ in 2 hours. The mixture was allowed to cool, transferred to a $250 \mathrm{~mL}$ volumetric flask, and diluted with deionized water. Again, $20 \mathrm{~mL}$, were removed from the cell for analyses. The samples of glass were dissolved in sealed Teflon vessels using $5 \mathrm{~mL}$ each of conc. HF and conc. HCl. This mixture was heated at $100^{\circ} \mathrm{C}$ for 1 hour, allowed to cool, and then transferred to a 
$250 \mathrm{~mL}$ volumetric flask. Five milliliters of conc. $\mathrm{HCl}$ along with $40 \mathrm{~mL}$ of $0.6 \mathrm{M} \mathrm{H}_{3} \mathrm{BO}_{3}$ were added to the flask. Boric acid was used to complex the $\mathrm{F}^{-}$ions. After dilution, $20 \mathrm{~mL}$ were removed from the cell for analyses. Concurrent with each of these dissolutions, a standard glass was dissolved to determine if the dissolutions were complete and the resulting analyses accurate. In all cases more than 6 aliquots of sampie were used for both dissolutions.

\section{Analytical Methods}

The major nonradioactive elements in the sludge and glass were determined by inductively coupled plasma - atomic emission spectrometry (ICP-AES). The instrument was modified to safely analyze radioactive solutions. The spectrometer was an Applied Research Laboratories Model 3580 with a 27 channel polychromater and a 12 meter Paschen-Runge scanning monochromator. The response of the instrument was calibrated using NIST traceable standards. Prior to analysis, the dissolution solutions from the Shielded Cells were further diluted 10X with $1 \%$ HNO3 to put the analytes in the ppm range.

Inductively coupled plasma - mass spectrometry (ICP-MS) analyses were made using a Fisons/VG PlasmaQuad ICP mass spectrometer operated in the scanning mode. This instrument was also modified so that radioactive solutions could be analyzed. Because we were analyzing for ffission products and actinides, special isotopic menus were created and abundances set at $100 \%$ rather the relying on a natural abundance menu. Indium was used as an internal standard and calibrations were performed with NIST traceable standards. Prior to analysis, the dissolution solutions from the Shielded Cells were further diluted with $1 \%$ HNO3 to put the fission products and actinides in the ppb range. Two dilution factors had to be used because of the range of concentrations in the solutions. 
For U-238 a factor of 2000 had to be used. For the others a factor of 20 was used.

Radioactive counting techniques were used to analyze for Cs-137, Sr-90, Pu-238, and Am-241. All other radionuclides were determined ICP-MS.

\section{RESULTS AND DISCUSSION}

\section{Major Nonradioactive Composition and the Sludge Dilution} Factor

The average concentrations of major nonradioactive elements (excluding oxygen) determined in Tank 51 sludge, glass, and SRS Frit 202 are given in Table 2. All the elements were measured by ICP-AES. The last column of Table 2 gives the sludge dilution factor (SDF). This is the factor by which the elements specific to the sludge were diluted by the addition of the Frit 202 in order to make glass. The concentrations in Table 2 for the sludge are averages from dissolution of 12 to 24 aliquots of the dried sludge slurry or glass. The relative standard deviations of these results are given in the Table in parentheses. The measured sludge composition in Table 2 is in excellent agreement with earlier measurements of that composition. 3 . When the sludge or glass was dissolved and analyzed, a standard glass was dissolved and analyzed concurrently as an analytical control check. The results for the standard glass were in excellent agreement with the known composition of the glass, indicating that the dissolution methods were complete, and that the ICP-AES instrument had been calibrated correctly.

Values for the SDF should all be equal if the analyses were completely accurate and if the dissolutions were complete. For the four major elements in the sludge, $\mathrm{Fe}, \mathrm{Al}, \mathrm{Mn}$, and $\mathrm{Ca}$, the average SDF is 3.07 with a $8 \mathrm{RSD}$ of $6.8 \%$ indicating 
good agreement. Nickel and phosphorous are specific to the sludge stream, but their results gave a lower value for the SDF. A possible reason for this may be the poor precision of the glass analyses for these two elements. Use of the SDF to estimate the concentrations of waste acceptance radionuclides that could not be measured in the glass will be discussed later.

\section{Radioactive Composition and the Radionuclide Dilution Factor}

Table 3 gives the radioactive composition of the sludge and glass. All the results except Sr-90, Cs-137, Pu-238, Pu-241, and Am-241 were determined by ICP-MS. Sr-90 was determined by beta counting, Cs -137 and Am-241 by gamma, and Pu-238 by alpha. Pu-241 was determined by a combination of gamma counting and ICP-MS. The last column of the Table presents the radionuclide dilution factor ( $R D F$ ). This is the factor by which each radionuclide is diluted by the addition of nonradioactive Frit 202 to the sludge. The concentrations in Table 3 are averages of six or more samples of the dried sludge or ground glass. Relative percent standard deviations ranged from less than $10 \%$ for major radionuclides to $32 \%$ for $\mathrm{Pu}-241$. The lack of precision for Pu-241 is because it is determined by the difference for the ICP-MS result for mass 241 and the contribution of Am-241 to that result determined by gamma counting. As can be seen in the Table Pu-241 accounts for only a small fraction of the total mass 241 detected. The most intense radiation frofin the sludge or glass is due to Sr-90 and its daughter Y-90. For example, the concentration of $\mathrm{Sr}-90$ in the sludge is $100 \mathrm{mCi}$ per 100 grams of dried sludge. The concentration of Cs-137 is much lower (only $6 \mathrm{mCi}$ per 100 grams) because most of the Cs-137 is not in the sludge slurry but is in the supernate tanks at SRS. 
All values for the RDF should all be equal and should equal the SDF since the radionuclides are specific to the sludge and the frit is nonradioactive. Values for Sr-90, Cs-137, and Am-241 determined by beta of gamma counting are within experimental error of 3.1. The value U-238, the major isotope determined by ICP-MS also agrees with 3.1. Ten out of twelve of the other values for the isotopes determined by ICP-MS are low suggesting that there may have been a systemic bias in determining these concentrations either in the sludge or glass. Such a bias could result from a matrix effect on the analyses since the actual solutions analyzed for these actinides in the ICP-MS were more concentrated than the solutions used to analyze for U-238. This is being investigated. Use of the RDF for estimating the concentrations of waste acceptance radionuclides that could not be measured in the glass will be discussed later.

\section{U-235 Fission Products in Tank 51 sludge and Glass}

The fission products in SRS HLW primarily result from the fission of U-235 used the SRS reactors to make neutrons. The concentrations of the low mass fission products measured in Tank 51 sludge and glass are plotted in Figure 1 as a function of mass number. Results for the high mass fission products appear in Figure 2. All the concentrations in both Figures were measured by ICP-MS except for Cs-137 which was determined by gamma counting. In both figures the solid circles indicate concentrations in the sludge and the solid squares indicate concentrations in the glass. It can be seen that for most of the isotopes; the concentrations in the glass are lower than those in the sludge by a constant factor. The open circles in both Figures are the fission yields of the respective isobaric mass chains from U-235 fission normalized to the concentration of that respective mass in the sludge. This normalization method is discussed 
below. For the low mass data in Figure 1, data below mass 88 are not presented because they were unreliable either due to the low concentrations of the fission products themselves (for example $\mathrm{Rb}-87$ ) or due to interferences from other elements at that respective mass such as the $\mathrm{Kr}$ isotopes present as impurities in the Ar plasma of the ICP-MS. The same argument applies to the high mass data in Figure 2 below mass 137. In this case it is the isotopes of the Xe impurity in the Ar that hinder accurate determinations.

Assignment of specific isotopes to these mass numbers is done by considering the half lives of the various radionuclides in the respective isobaric fission chains from fission of $\mathrm{U}-235$. In each chain usually the element with the longest half life is assigned to that mass. These assignments have been discussed in two other publications 4,5 where the fission product concentrations in the sludges in SRS waste Tank 4 and Tank 15 were measured and presented in the same format.

In both Figure 1 and Figure 2 the lower concentrations in the glass are clearly evident except at masses 90 to 94 and masses 139 and 155. In Figure 1 the higher concentrations in the glass at masses 90, 91, 92, and 94 are due to isotopes of natural $\mathrm{Zr}$ which found to be a slight impurity in the Frit 202. The ion showing the high concentration at mass 93 in the glass is unknown at this time. It is thought to be a molecular ion resulting from $\mathrm{F}^{-}$ions used to dissolve the glass interacting with the plasma system for the inlet system of the mass spectrometer. In Figure 2 for the high mass fission products, the response at mass 139 is due to La that was added as a tracer to the melter in the Tank 51 demonstration. The response at mass 155 is due to the $\mathrm{LaO}^{+}$ molecular ion formed in the plasma of the ICP-MS. 6 All the other isotopes in both mass ranges are diluted in the glass. The dilution appears to be relatively the same indicating a constant sludge or radionuclide dilution factor. 
The normalization method will now be discussed. The open circles in both figures were calculated based on the known fission yields and the measured concentrations in the sludge of those U-235 fission products that meet the following five criteria. The isotopes selected had to have low solubilities in caustic and thus occur predominantly in the sludge. They had to have long half lives and thus had not decayed significantly since the waste was generated. The isotopes had to have low neutron cross sections and thus were not transmuted in the SRS reactors during their operation. The isotopes could not be formed in the reactors by neutron absorption. Lastly the isotopes had to have masses where interferences such as those from rare earth oxide ions formed in the Ar plasma did not create a problem. Table 4 lists the eleven isotopes that meet these criteria. Note that isotopes from both the low mass and high fractions of the fission of U-235 are included. Table 4 presents the known fission yields of the isotopes (taken from Reference 7), their average concentrations in the sludge, and the fission yield scaling factors (FYSF) calculated by dividing the fission yield by the concentration of that respective isotope in the sludge. The average calculated FYSF based on the eleven isotopes was $2.7 \mathrm{E} 03$ with a standard deviation of $0.4 \mathrm{E} 03$.

Except for some striking deviations, the measured concentrations in the sludge closely follow the scaled fission yields, as expected. In Figure 1 for the low mass fission products in the sludge; the disagreement at mass 88 could result from natural $\mathrm{Sr}-88$ in the sludge possibly added as an impurity with the caustic used to neutralize the waste. Masses 89 through 94 and mass 96 are formed with nearly equal fission yields. Their concentrations are low compared to the normalized fission yield curve. Mass 89 is assigned to $Y-89$ and mass 90 to a mixture of $\mathrm{Sr}-90, \mathrm{Y}-90$ and $\mathrm{Zr}-90$. Masses 91, 92, 93, 94, and 96 are assigned to the remaining $\mathrm{Zr}$ fission 
product isotopes. The results for all these masses may be low due to incomplete dissolution in sludge samples for $\mathrm{Y}$ and $\mathrm{Zr}$. We are currently investigating the possibility of incomplete dissolution. The isotopes assigned to masses 95, 97, 98, and 100 are Mo fission products. These are soluble in caustic as the molybdate anions $\left(\mathrm{MOO}_{4}=\right)$. Consequently, their concentrations are low in the sludge because they have been transferred to a supernate tank. The deviations from this curve at masses 106 to 112 are due to natural Ag and Cd being present in the waste. Silver results from Ag that was used to scavenge radioactive iodine isotopes released when the fuel was dissolved at SRS. Cadmium was used in certain fuel rods in the SRS reactors to shape the neutron energy spectrum. The Cd was then dissolved with the fuel rods and eventually added to the waste. In Figure 2 for the high mass fission products, the concentration at mass 137 is for Cs-137 determined by gamma counting. It is low compared to the normalized fission yield curve because Cs is soluble in caustic and most of it has been transferred to a supernate tank. The result for mass 138 is high because of natural $\mathrm{Ba}$ being in the waste, presumably added as an impurity with some process chemical. Masses 140 and 142 are assigned to natural Ce - again possibly added as an impurity. Masses 149 and 151 are assigned to $\mathrm{Sm}$ isotopes. Their concentrations are low because they have been transmuted in the SRS reactors due to their large isotopic neutron absorption cross sections. This accounts the relatively high concentrations of Sm-150 and Sm152. At masses 153 and above the concentrations do not agree with the scaled fission yields due to the contributions of the alkaline earth oxides formed in the plasma. for example ${ }^{138} \mathrm{BaO}^{+}$with a mass of 154 contributes to the response at this mass. Since the yields of the fission products are accurately known and since the only source of the radioactive fission products is predominantly the fission of U-235, the concentrations of the other long-lived fission products can 
be predicted from the data in Figures 1 and 2. For example, the concentration of the waste acceptance radionuclide Pd-107 (the long lived isotope resulting from the beta decay of the 107 isobaric fission chain) could not be determined in Tank 51 sludge or glass due to the presence of natural Ag-107 in the sludge. From the open circles in Figure 1, the concentration of $\mathrm{Pd}-107$ is predicted to be $7 \mathrm{E}-04$ wt $\%$.

\section{Use of the SDF or RDF and the FYSF to Estimate Se-79, Zr-93, and Pd-107 Concentrations in Tank 51 Glass}

Selenium-79 (a fission product required for waste acceptance) could not be measured by ICP-MS in the dissolved sludge or glass because of its low concentration and the interference of natural $\mathrm{Br}-79$ in the $\mathrm{HCl}$ used to dissolve the sludge and glass. Since the only source of Se-79 in the waste is the fission of U-235, the concentration of Se-79 in the sludge can be calculated from its fission yield and the fission yield scaling factor of 2.7E03. The known fission yield of Se-79 is $0.056 \% .7$ (This is more than 100X lower than the yield for Sr-90.) The predicted concentration of se-79 in the sludge is then $0.056 / 2.7 \mathrm{E} 03$ or $2.1 \mathrm{E}-05 \mathrm{wt} \%$. This value can be considered an upper limit for the concentration of Se79 in Tank 51 sludge. The actual concentration of se may be lower in the sludge if $\mathrm{Se}$ is somewhat soluble in caustic and some has been transferred to a salt supernate tank with the Cs-137. With a SDF or RDF of 3.1 , the predicted concentration of Se-79 in the glass is 2.11E-05/3.07 or 6. 8E-06 wt\%. Since the calculated concentration in the sludge is a maximum, the concentration in the glass is given as $\leq 6.8 \mathrm{E}-06$ wt\%.

The concentration of Zr-93 could not be measured in the Tank 51 glass because of the appearance of the molecular ion at mass 93 from the plasma of the ICP-MS (see Figure 1). The concentration of $\mathrm{Zr}-93$ in the sludge was $1.1 \mathrm{E}-03$ wt\%. Using 
the SDF or RDF of 3.1, the concentration of $\mathrm{Zr}-93$ in the glass would be $1.1 \mathrm{E}-03 / 3.1$ or $3.6 \mathrm{E}-04 \mathrm{wt} \%$. It has been stated earlier that there may have been incomplete dissolution of the $\mathrm{Zr}$ which accounts for the low concentrations shown in Figure 1 for the $\mathrm{Zr}$ isotopes. The fission yield of Zr-93 is $6.40 \% .7$ Based on a FYSF of 2.7E03, a concentration of $2.4 \mathrm{E}-03 \mathrm{wt} \%$ is predicted for $\mathrm{Zr}-93$. Based on this concentration in the sluage, the concentration in the glass would be $7.7 \mathrm{E}-04 \mathrm{wt} \%$. The possibility of incomplete dissolution is being investigated in an attempt to determine the reason for the low measured concentration of Zr-93.

The concentration of Pd-107 in the sludge was estimated to be 7E-04 wt: using the FYSF. The concentration in the glass would be 2E-04 wt\% based on the value of 3.1 for the SDF and $\mathrm{RDF}$.

\section{ACKNOWLEDGMENT}

Work performed under Contract No. DE-AC09-89SR18035 with the U.S. Department of Energy.

\section{REFERENCES}

1. Office of Environmental Restoration and Waste Management, Waste Acceptance Product Specifications for Vitrified High-Level Waste Forms, Revision 0, USDOE Document EM-WAPS, U.S. Department of Energy, Germantown, MD (1993).

;

2. Andrews, M. K. and Bibler, N. E., "Radioactive Demonstration of DWPF Product Control strategy", Ceramic Transactions, Volume 39, p 205, The American Ceramic Society, Westerville, OH (1994).

3. Coleman, C. J., Bibler, N. E., Dewberry, R. A., "Analysis of High Level Radioactive Glasses and Sludges for the Savannah River Site," Waste Management 90, WM Syrnposia, Inc., Roy G. Post, Editor, pp. 651-657, (1990). 
14

WSRC-MS-97-0011

4. Bibles, N. E., C. J. Coleman, and W. F. Kinard, "Relative Yields of U-235 Fission Products Measured in a High Level Radioactive Sludge at the Savannah River Site", Nuclear and Hazardous Waste Management Spectrum '92, American Nuclear Society, Inc., La Grange, IL, page 952, (August, 1992).

5. Bibles, N. E., Coleman C. J., Kinard W. F., and Wyrick, S. B., "Inductively Coupled Plasma - Mass Sprectrometry Studies of the Chemistry of Fission Products and Actinides in High level Wastes: Lessons That Can be Applied to Environmental Measurements", Radiochimica Alta, Vol 66-67, p. 259-263 (1994).

6. Houk, R. S., "Mass Spectrometry of Inductively Coupled Plasmas", Analytical Chemistry, Vol. 58, No. 1, pp. 97A105A, (January, 1986).

7. Walker, W. H., "Status of Fission Product Yield Data for Thermal Reactors", Review Paper 11a for the IAEA Panel on Fission Product Nuclear Data, Bologna Italy, 11/26-11/30, 1973, (IAEA-169, Volume 1, 285 \{1974\}). 
Table 1. Examples of Fission Product and Actinide Radionuclides That Need To Be Reported for Waste Acceptance

Fission

Products

$\begin{array}{ll}\mathrm{Se}-79 & 3.3 \mathrm{E} 04 \\ \mathrm{Sr}-90 & 38 \\ \mathrm{Zr}-93 & 1.5 \mathrm{E} 06 \\ \mathrm{Tc}-99 & 2.1 \mathrm{E} 05 \\ \mathrm{Pd}-107 & 6.5 \mathrm{E} 0 \\ \mathrm{Cs}-137 & 30 \\ \mathrm{Sm}-151 & 90\end{array}$

Actinides

$\mathrm{U}-234$

$\mathrm{Np}-237$

$\mathrm{Pu}-238$

$\mathrm{U}-238$

$\mathrm{Pu}-239$

$\mathrm{Pu}-240$

$\mathrm{Pu}-241$

Am-141

$\mathrm{Pu}-242$

Am-243

$\mathrm{Cm}-244$
Half Life (y)

2. 5E05

2. $1 \mathrm{E} 06$

88

4. 5E09

$2.4 \mathrm{E} 04$

$6.6 \mathrm{E0} 3$

14

$4.3 \mathrm{E} 02$

3. $8 \mathrm{E} 05$

7. $4 \mathrm{E} 03$

18 
Table 2. Major Elements (Excluding $\mathrm{O}_{2}$ ) in SRS Washed Tank 51 sludge, Frit 202, and Final Radioactive Glass, and the sludge Dilution Factora

\begin{tabular}{|c|c|c|c|c|}
\hline Element & $\begin{array}{l}\text { wt. } \% \text { in } \\
\text { sludge }^{b}\end{array}$ & $\begin{array}{l}\text { wt.\% in } \\
\text { Frit }\end{array}$ & $\begin{array}{c}\text { Wt. \% in } \\
\text { Glass } \\
\end{array}$ & $\begin{array}{l}\text { Sludge } \\
\text { Dilution Factorc }\end{array}$ \\
\hline $\begin{array}{l}\mathrm{Fe} \\
\mathrm{Al} \\
\mathrm{Mn} \\
\mathrm{Ca} \\
\mathrm{P} \\
\mathrm{Ni} \\
\mathrm{Na} \\
\mathrm{Mg} \\
\mathrm{Si} \\
\mathrm{Li} \\
\mathrm{B}\end{array}$ & $\begin{array}{l}28.50(4.0) \\
8.38(4.3) \\
3.09(3.8) \\
2.75(3.7) \\
0.60(8.5) \\
0.35(2.9) \\
2.65(6.7) \\
1.43(4.4) \\
0.67(11) \\
<0.05 \\
<0.05\end{array}$ & $\begin{array}{c}- \\
- \\
- \\
- \\
- \\
- \\
4.5 \\
1.2 \\
36 . \\
3.3 \\
2.5\end{array}$ & $\begin{array}{c}9.21(5.2) \\
2.56(4.9) \\
0.98(7.3) \\
0.99(7.7) \\
0.26(18) \\
0.23(14) \\
6.96(8.0) \\
1.24(3.9) \\
24.50(3.3) \\
2.10(2.8) \\
2.00(1.2)\end{array}$ & $\begin{array}{l}3.09 \\
3.27 \\
3.15 \\
2.78 \\
2.30 \\
1.50\end{array}$ \\
\hline
\end{tabular}

a Relative standard deviations (percent) are given in the parentineses.

bsludge aried at $100^{\circ} \mathrm{C}$

calculated by dividing the concentration of an element in the sludge by its respective concentration in the glass. 
Table 3. Radioactive Composition of Washed Tank 51 sludge and Final Radioactive Glass, and the Calculated Radionulcide Dilution Factor

\section{Radionuclide}

$$
\begin{gathered}
\mathrm{Sr}-90 \\
\mathrm{Cs}-137 \\
\mathrm{Sm}-151 \\
\mathrm{Th}-232^{\mathrm{C}} \\
\mathrm{U}-233 \\
\mathrm{U}-234 \\
\mathrm{U}-235 \\
\mathrm{U}-236 \mathrm{C} \\
\mathrm{Np}-237 \\
\mathrm{Pu}-238 \\
\mathrm{U}-238 \\
\mathrm{Pu}-239 \\
\mathrm{Pu}-240 \\
\mathrm{Pu}-241 \\
\mathrm{Am}-241 \\
\mathrm{Pu}-242 \\
\mathrm{Am}-243 \\
\mathrm{Cm}-244
\end{gathered}
$$

\begin{abstract}
Wt.\% in
\end{abstract}
sludge

$7.3 \mathrm{E}-04$

$6.7 \mathrm{E}-05$

$7.0 \mathrm{E}-05$

$4.9 \mathrm{E}-02$

2. 5E-04

3. $4 \mathrm{E}-04$

1. $6 \mathrm{E}-02$

1. $3 \mathrm{E}-03$

1. $5 \mathrm{E}-03$

5. $0 \mathrm{E}-04$

3. $0 \mathrm{E}-00$

7. $8 \mathrm{E}-04$

7. $0 \mathrm{E}-04$

1. $9 \mathrm{E}-05$

2. $4 \mathrm{E}-04$

8. 3E-05

4. $4 \mathrm{E}-05$

1. $9 \mathrm{E}-05$
Wt.\% in

Glass

2. 3E-04

2. $2 E-05$

$3.5 E-05$

1. $7 \mathrm{E}-02$

1. $2 \mathrm{E}-04$

1. $6 \mathrm{E}-04$

7. $6 \mathrm{E}-03$

6. 1E-04

4. $2 \mathrm{E}-04$

1. 1E-04

9. $7 \mathrm{E}-01$

2. $2 \mathrm{E}-03$

3. $0 \mathrm{E}-04$

4. $2 \mathrm{E}-06$

7. $4 \mathrm{E}-05$

3. $5 \mathrm{E}-05$

2. $2 \mathrm{E}-05$

1. $1 \mathrm{E}-05$
Radionuclide

Di1. Factor ${ }^{b}$

3.2

3.0

2.0

2.9

2.1

2.1

2.1

2.1

3.6

4.5

3.1

3.5

2.3

4.5

3.2

2.4

2.0

1.7

asludge âried at $100^{\circ} \mathrm{C}$

bCalculated by dividing the concentration of an element in the sludge by its respective concentration in the glass.

cNot necessary for Waste Acceptance 
Table 4. Calculation of the Fission Yield Scaling Factor Based on the Concentrations of Eleven U-235 Fission Products Measured in Dried Tank 51 Sludge.

Isotope

$\mathrm{Ru}-101$

$\mathrm{Ru}-102$

$\mathrm{Rh}-103$

$\mathrm{Ru}-104$

Pd-105

Pr -141

Nd-143

Nd-144

$\mathrm{Nd}-145$

Nd-146

Sm-147
Fission Yield $(\%)^{a}$

5.05

4.19

3.12

1.83

0.93

5.82

5.95

5.39

3.93

2.97

2.25
Concentration

in Dried sludge

1. $5 \mathrm{E}-03$

1. $3 E-03$

1. $4 \mathrm{E}-03$

7. $2 \mathrm{E}-04$

3. $6 \mathrm{E}-04$

$2.3 E-03$

2. $0 \mathrm{E}-03$

2. $3 E-03$

1. $4 \mathrm{E}-03$

1. $2 \mathrm{E}-03$

7. 3E-04
Fission Yield

Scaling Factor

$3.37 \mathrm{E0} 3$

3. $22 \mathrm{E} 03$

2. 23E03

2. $54 \mathrm{EO} 03$

2. 58E03

2. $53 \mathrm{E} 03$

2. $98 \mathrm{E} 03$

2. 34E03

2. 81E03

$2.48 \mathrm{E} 03$

$3.07 \mathrm{E} 03$

Average $=(2.74 \pm 0.37) \mathrm{E} 03$

$a_{\text {Taken }}$ from Reference 7 . 


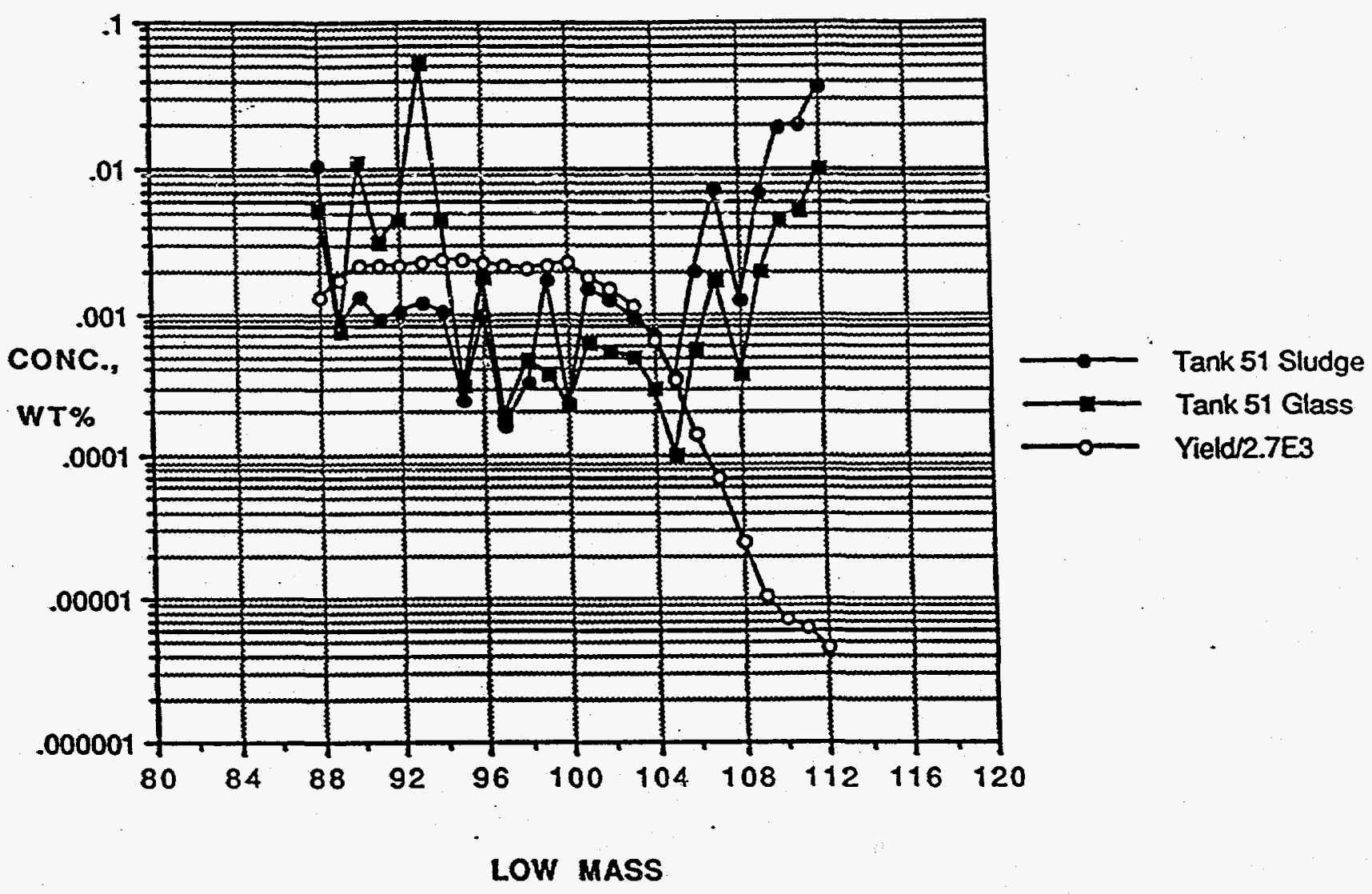

Figure 1. Measured concentrations of U-235 low mass fission products and stable isotopes of $\mathrm{Ag}$ and $\mathrm{Cd}$ in Tank 51 sludge and glass compared to the known fission yields from Ref. 7 . The fission yields (in percent) have been normalized to the measured concentrations in the sludge 'by dividing the yield by the fission yield scaling factor (FYSF) calculated as described in the text. The FYDF was $2.7 \mathrm{E0} 3$ based on the measured concentrations of 11 fission products. 


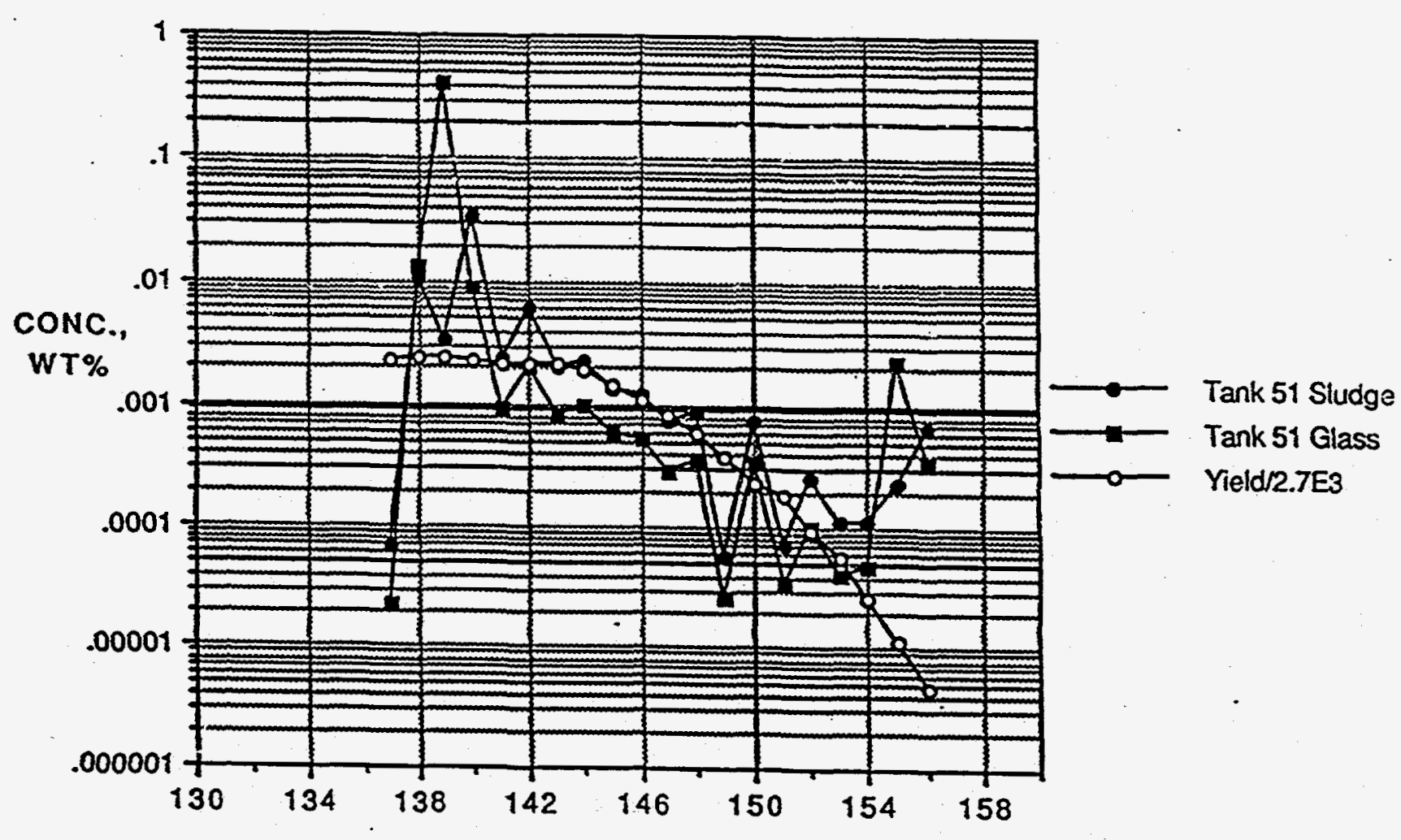

HIGH MASS

Figure 2. Measured concentrations of U-235 high mass fission products and La in Tank 51 sludge and glass compared to the known fission yields from Ref 7. The fission yields (in percent) have been normalized to the reasured concentrations in the sludge by dividing the yield by the fission yield scaling factor (FYSF) calculated as described in the text. The FYDF was $2.7 \mathrm{E} 03$ based on the measured concentrations of 11 fission products. 